\title{
Kapea-alaista koulutussuunnittelua hallinnon tarpeisiin
}

Aikuiskasvatuksessa koulutustarpeen maarittely voi tapahtua joko yhteiskunta-, organisaatio- tai yksilötasolla. Perinteisistä koulutussuunnittelun menetelmistä työvoimamenetelmä edustaa selvimmin koulutustarpeen selvittämistä yhteiskunnan näkökulmasta. Organisaatiot - erityisesti taloudelliset yritykset ovat kiinnostuneet koulutuksen kustannushyöty suhteesta ja käyttävät mielellään tähän liittyviä suunnittelumenetelmiä. Erityisesti vapaaehtoisuuteen perustuvassa aikuisopiskelussa koulutussuunnittelun lähtökohtana on ollut yksilöiden kiinnostus, eli suunnittelu on perustunut ns. kysyntämenetelmään. Koulutustarpeen selvittämisen tasot ja menetelmät eivät luonnollisestikaan vastaa aivan näin yksiselitteisesti toisiaan, mutta joka tapauksessa tietynlainen tarkastelutaso implikoi yleensä varsin vahvasti myös käytettävää suunnittelumenetelmää.

Koulujärjestelmän piirissä suunnittelu on meillä perinteisesti pohjautunut työvoimamenetelmään, eli on pyritty mitoittamaan koulutettavien määrät ja opintojen sisällöt mahdollisimman tarkasti työmarkkinanäkymien mukaan. Muunlaista lähestymistapaa suomalaisesta koulutussuunnittelusta saa hakea suurennuslasin kanssa. Työvoimamenetelmän keskeisyys on osoitus siitä, että koulutussuunnittelijat nạ̈kevät yhteiskunnan edelleen mekanistis-deterministisesti ja että heidän ihmiskäsityksensä on kapea-alainen ja tuotantokeskei- nen. Erityisen huonosti näin kapea-alainen lähestymistapa sopii aikuiskasvatukseen.

Koulutussuunnittelun neuvottelukunnan raportissa Väestön koulutus 2000 on esitetty laskelmia aikuisten ammatillisesti eriytyneestä koulutustarpeesta vuonna 2000. Kokonaan tarkastelun ulkopuolelle on jätetty aikuisten yleissivistävä ja harrastusopinnot. Tavallaan asian kyllä ymmärtää, koska juuri viimeksimainittujen aikuiskasvatuksen alueiden määrällinen arviointi on kieltämättä vaikea tehtävä. Tällaisen koulutustarpeen selvittäminen ei voi myöskään perustua koulutetun työvoiman määrällisen kehityksen arviointiin, kuten neuvottelukunnan raportissa on tehty.

Neuvottelukunnan valitseman lähestymistavan takia raportissa on jouduttu ensisijaisesti keskittymään väestön perus- ja uudelleenkoulutustarpeen määrälliseen ennustamiseen. Hyvänä puolena voidaan pitää sitä, että raportissa on otettu huomioon sekä nuoruusiän että aikuisväestön koulutustarpeet; nämähän liittyvät osittain luonnollisesti toinen toisiinsa.

Aikuisväestön ammatillisen perus- ja uudelleenkoulutustarpeeksi on arvioitu vuonna 2000 noin 50000 henkilöä. Suurimman osan tästä koulutustarpeesta arvioidaan huolehdittavan työllisyys- tai vastaavan koulutuksen avulla. Muu aikuisten ammatillinen perus- ja uudelleenkoulutus tapahtuu raportin mukaan erilaisten ammatillisten oppilaitosten ja oppisopimuskoulutuksen kautta. Aikuisten opettaminen yleistyy ja vakinaistuu näin myös ammatillisissa oppilaitoksissa lähitulevaisuudessa. 
Kun aikuisten hakeutuminen ammatillisten oppilaitosten kursseille riippuu viime kädessä aikuisista itsestään, niin nähtäväksi jää, saavutetaanko asetetut tavoitteet. Ainakaan itsestään selvä asia se ei ole. Avainkysymys tietysti on, miten aikuiset arvioivat koulutuksesta saatavan hyödyn ja miten aikuisten opintojen aikainen toimeentulo kyetään turvaamaan.

Jatkokoulutuksen kokonaistavoitteeksi vuonna 2000 on asetettu 30000 aloittajaa, mikä on noin kolmanneksen nykyistä aloittajien määrää suurempi. Näissä luvuissa ovat mukana vain koulu-, opistoasteen tutkinnon sekä korkea-asteen tutkinnon suorittaneille yhteiskunnan koulutusjärjestelmässä annettava jatkokoulutus.

Täydennyskoulutukselle ei neuvottelukunta ole katsonut voivansa esittää mitään numeerisia tavoitteita, vaikka joitakin arvioita senkin yleistymisestä on tehty.

Tämä on vahinko, kuitenkin nimenomaan työvoiman täydennyskoulutustarpeen selvittämistä voidaan perustellusti pitää tällä hetkellä yhtenä keskeisimpänä koulutuspoliittisena kysymyksenä. Tällä alueella koulutuksen järjestämis- ja kustannusvastuukysymykset ovat kuitenkin vaikeimmin ratkaistavissa, mikä on ehkä aiheuttanut sen, että neuvottelukunta on jättänyt nämä kysymykset kokonaan tarkastelunsa ulkopuolelle.

Neuvottelukunnan raportin keskeisin anti aikuiskasvatusta ajatellen on siis aikuisten ammatillisen perus- ja uudelleenkoulutustarpeen selvittäminen. Kuten Kivinen ja kumppanit tässä lehdessä olevassa artikkelissaan osoittavat, sisältyy näihinkin laskelmiin monia virhemahdollisuuksia. Osa virhemahdollisuuksista johtuu puhtaasti laskennallisista lähtökohdista ja osittain työmarkkinaosapuolten halusta korostaa oman toiminta-alueensa koulutustarpeita. Näistä syistä johtuen tehtyihin laskelmiin täytyy suhtautua varovasti.

Aikuiskasvatuksen suunnittelu tarvitsisi kipeästi perustakseen olemassa olevan koulutustoiminnan jatkuvaa ja kattavaa tilastotietoa. Tätä neuvottelukuntakin aivan oikein esittää. Tämän lisäksi tarvittaisiin tarkempia alakohtaisia koulutustarveanalyyseja, joissa tulisi selvittää eri henkilöstöryhmien täydennyskoulutustarpeet sekä niiden tyydyttämisessä tarvittavat resurssit.

Jatkuvan kasvatuksen periaatteen näkökulmasta koulutustarpeita selvitettäessä keskeiseksi kysymykseksi näyttää muodostuvan se, miten yhteiskunnan, organisaatioiden ja yksilöiden koulutustarpeet tulisi ottaa huomioon ja miten niitä pitäisi painottaa. Tähän kysymykseen neuvottelukunnan raportti ei anna mitään vastausta. Jotta tällaiseen keskusteluun päästäisiin olisi koulutustarvetutkimus vietävä lähemmäksi yhteiskunnan eri organisaatioita ja niissä toimivien ryhmien ja yksilöiden todellisuutta. 